\title{
Education and Hospitality in Liminal Locations for Unaccompanied Refugee Youths in Lesvos
}

\author{
Ivi Daskalaki and Nadina Leivaditi
}

\begin{abstract}
The closure of borders along the "Balkan route" and the EU-Turkey agreement in 2016 resulted in the involuntary immobility of thousands of refugees in Greece. Since then, the large-scale emergency relief aid on the Greek shores has been replaced by the development of provisions for the gradual integration of refugees within wider European society. In such a context, education comes to the fore in the management of Europe's so-called "refugee crisis." This article explores refugee youths' educational engagements in the framework of their "temporary" accommodation in a Transit Shelter for Unaccompanied (Male) Minors on the island of Lesvos. The article discusses how the youths themselves act upon educational arrangements made by their caretakers within a context of limited agency inscribed in a "code" of filoxenia (hospitality to foreigners). This code positions refugee youths both as temporary "guests" and simultaneously as "subjects" of discipline in the residency and in wider society.
\end{abstract}

KEYWORDS: discipline, education, hospitality, refugee crisis, unaccompanied refugee youth

The "humanitarian crisis" on the shores of Greece reached its peak in 2015, mobilizing multiple agents-national and international non-governmental organizations (NGOs), international bodies, local authorities, and volunteers-towards the development of diverse actions of "emergency" support and "solidarity" for refugees (Papataxiarchis 2016a, 2016b, 2016c, 2016d; Rozakou 2016). Following the closure of state borders along the Balkan route and the implementation of the EU-Turkey agreement in March 2016, ${ }^{1}$ which resulted in the prolonged entrapment of approximately 50,000 refugees in Greece, ${ }^{2}$ refugee education has progressively become one of the prime terrains of the management of the "refugee crisis" in the country. In fact, as the refugee crisis in Greece enters a new phase (Papataxiarchis 2016c: 23) marked by a shift from emergency mobilization for the purposes of large-scale relief aid and to meet refugees' basic needs towards developing short- and long-term provisions for refugees' integration within wider European society, education has increasingly come to the forefront of policy responses (Scientific Committee for the Support of Refugee Children 2017). Simultaneously, as "the refugee" is increasingly no longer seen in Greek society as a transit "guest" in an extremely vulnerable state, but rather as a potential permanent resident, "hospitality" rather than "solidarity" re-emerges as a prevailing form of engagement with refugees within the overarching framework of humanitarian practice (Papataxiarchis 2016c: 23-26; 2016d: 207).

This article explores unaccompanied refugee youths' experiences of forced migration through a focus on processes of education, with the latter being intrinsic to practices of "hospitality" in 
the context of their temporary accommodation in a Transit Shelter for Unaccompanied (Male) Minors on the island of Lesvos. Specifically, by concentrating on the youths' stance towards their expected participation in formal, remedial, and recreational educational activities, the article discusses how the youths themselves act upon educational arrangements made by their caretakers within a context of limited agency inscribed in a code of filoxenia (hospitality). This code positions refugee youths both as temporary "guests" and yet also as subjects of discipline in the residency. The article is based on data produced through eight months of ethnographic fieldwork conducted at the Transit Shelter for Unaccompanied (Male) Minors on the island of Lesvos between October 2016 and May 2017, in the framework of the PRESS Project, funded by the Hellenic Open University. ${ }^{3}$

Fieldwork undertaken at the shelter has been part of a wider team-based interdisciplinary research project examining refugee education in Greece. This has involved social anthropologists and sociolinguists working jointly in three different geographical sites-namely in Lesvos, Attica, and Thessaloniki-under the supervision of three project coordinators. ${ }^{4}$ Methodologically, the research was grounded in a synthesis of primarily qualitative research methods that combined ethnographic participatory fieldwork with linguistic ethnography. The main methodological tool of the research was ethnographic (multi-sited) field research. Additionally, the research adopted child-centered methods, such as assigned projects, drawings, and role plays, in tandem with methods that can be used in combined research with children, youth, and adults, such as narratives, life histories, and informal discussions. The research also adopted methods suitable for linguistic and educational research in non-formal and informal educational settings, such as classroom interactions, language portraits, semi-structured interviews, focus groups, and diaries. Since the research took place in multilingual fieldwork settings (Holmes et al. 2013), the researchers and research assistants who had diverse linguistic backgrounds (speaking Greek, English, Arabic, Farsi, Kurmanji, and French, among other languages) engaged themselves in multilingual research processes throughout all stages of the project, ranging from research design to implementation and the interpretation of data.

The researchers remained committed to the principles of being open, clear, and sincere about the aims and objectives of the research, and worked within a framework of guaranteeing interviewees' anonymity and confidentiality. These principles and this framework were essential as we requested and obtained access to our research sites and were able to recruit and gain consent from children/youth, parents, site managers, and educators. Primarily, the researchers sought to establish relationships of trust with refugees and to respond with sensitivity, flexibility, and common sense to the particularity of each research case "through a reflexive research practice" (Christensen and Prout Christensen and Prout, 2002: 493), especially when the recounting of traumatic experience by underage participants was involved. Considering the limitations in communication in multilingual research settings, the researchers were cautious to create appropriate linguistic environments that would enable the research participants of different ages to express themselves in various ways (e.g. using one or more language(s) with or without the presence of interpreter(s) or switching between language(s)). ${ }^{5}$ The researchers were also careful to identify and address any asymmetries and power relations, for example among children and youth within the family, the accommodation site and the class-room setting, or between children/youth and adults, such as relatives, educators, NGO staff, and volunteers. This led to rearrangements in the methodology to minimize such asymmetries and imbalances in research encounters.

Within the broader thematic domain of refugee and forced migration studies (FiddianQasmiyeh et al. 2014), a topic of relevance increasingly addressed is that of refugee education (e.g. Chatty et al. 2014; Dryden-Peterson 2015, 2017; Fiddian-Qasmiyeh 2015; Hos 2016), along with that of refugee children and youth (e.g. Boyden and de Berry 2004; Chatty 2007, 2010; 
Hart 2008, 2014). This article draws theoretically on the aforementioned strands of the literature in tandem with anthropological approaches to education (e.g. Anderson-Levitt 2011, 2012; Levinson and Pollock 2011) and youth (e.g. Amit-Talai and Wulff 1995; Korbin 2003; Levine 2007; Best, 2007; Punch and Tisdall 2014), as well as on recent ethnographic studies on the "refugee crisis" and the biopolitics of "hospitality" and "solidarity" in austerity-stricken Greece (e.g. Athanasiou 2017; Papataxiarchis 2016a, 2016b, 2016c, 2016d, 2017; Rakopoulos 2015; Rozakou 2008, 2012, 2016).

The discussion is premised on the following theoretical acknowledgments: firstly, that children and young people are social agents who actively engage with social processes and the interdependencies of relatedness that shape their lives even in constrained contexts; secondly, that education plays a prominent role in this engagement; thirdly, that mainstream educational processes provide a principal arena in which top-down disciplinary techniques are articulated upon children and youth. Acknowledging the above, the article addresses the topic of refugee youth education in a state of prolonged "transit." It does so in the context of everyday interactions and sociality between unaccompanied male youths and the caretakers employed by the NGO that runs the accommodation site. As demonstrated in ethnographic literature on Greece (Papataxiarchis 2006, 2016c, 2017; Rozakou 2012), the tangible relationships developed at the mundane level between refugees and those engaged in the humanitarian sector are inscribed in the dominant discourse on filoxenia and the concomitant production of the powerful notions of refugees as "guests" and humanitarian agents as "hosts." Filoxenia-the Greek word for hospitality, meaning filia (friendship) towards the xenos (stranger), or kindness towards the stranger (Cabot 2013: 152) —ascribes a significant historically-specific cultural value to popular and official representations of what it means to be Greek (Cabot 2013; Du Boulay 1991; Herzfeld 1987, 1997; Papataxiarchis 2006, 2016c, 2017; Rozakou 2012). Filoxenia is approached here from an emic viewpoint as a culturally and historically specific mode that shapes everyday socialities (Papataxiarchis 2006, 2016c, 2017; Rozakou 2012). Simultaneously, though, the article brings into discussion the refugee youths' own understandings of "hospitality" and how these inform everyday practices and relations with local people and humanitarian agents.

In the context of the rapid transformations that have been taking place in Greek society during the last decades (i.e. the migrant flows of the 1990s and 2000s and the more recent refugee crisis), filoxenia signifies a prevailing mode of dealing with otherness, albeit a contested one within an emerging discourse on "solidarity" in the present context (Papataxiarchis 2016c, 2016d; Rozakou 2016; Rakopoulos 2015). In such a context, the offering of filoxenia vis à vis the xenos subtly positions the guest as inferior in the host's system of values, and constantly challenges the former to adopt the values of the latter, while simultaneously reproducing an ethnocentric view of the superiority of the host (Papataxiarchis 2006: 6; 2016c: 8).

With reference to the shelter in Lesvos, called in everyday speech by residents and carers alike "to spiti" (home), practices of "hospitality" constituted important aspects of a domestic sociality in a site with great symbolic value (for both refugees and members of the host society), connoting culturally significant systems of kinship and family. Indeed, ethnographic studies in Greece have depicted the domestic sphere and the household as the prime terrain in which filoxenia is deployed (e.g. Herzfeld 1987) and as a domain of cross-cultural interactions (e.g. Papataxiarchis 2006; Papataxiarchis et al. 2009). The daily routines of the young residents-"guests" and their caretakers, the latter acting as "hosts" in the house-involved the "intimate sharing of space," in Janet Carsten's (2004: 35) words, through activities such as sleeping, cooking, eating, chatting, and undertaking household tasks. In effect, not only did these routines produce domestic relations of co-existence (Sahlins 2013: 73) but they also produced family-like intragenerational asymmetrical relationships between the male youths and the female and male car- 
ers. An example of this is a relationship that resembled that of a younger sibling (resident) with an older brother/sister or mother (caretaker), depending on the carer's gender and age.

At a time when the education of refugee children has been emerging as a crucial issue in the management of the refugee crisis, the caretakers' discourse of offering filoxenia towards the vulnerable young guests co-existed with the caretakers' expectations of reciprocity by these same "guests" through their active engagement in various kinds of learning activities. The youths responded positively to the caretakers' assignments, fulfilling, in a sense, the latter's expectations, while claiming their visibility inside and outside the shelter. However, at the same time, they renegotiated to their own ends the form and content of educational activities, and claimed more intimate relationships with their preferred caretakers by re-appropriating dominant concepts of domesticity as being incompatible with certain forms of educational processes taking place within the house. Yet in doing so, they also reproduced the existing "hospitality" order.

\section{The Transit Shelter for Unaccompanied Minors (UAM) in Lesvos}

The island of Lesvos is located in the north-eastern part of the Aegean Sea, only $10 \mathrm{~km}$ away from the Turkish coastline. Since the mid 2000s, Lesvos has been one of the main entrance "gates"-a "doorstep" in Heath Cabot's (2014) terms-of migrant flows coming from the Middle East, Asia, and North Africa, through Turkey to Europe and forming the so-called Eastern Mediterranean route (Papataxiarchis 2016a: 5). In 2015 alone, 856,723 refugees and migrants crossed the Aegean Sea and arrived in Greece, almost half of them reaching the shores of Lesvos (Papataxiarchis 2016c: 10). ${ }^{6}$ In the whole of 2016, following the closure of the borders along the Balkan route and the implementation of the EU-Turkey agreement, the refugees and migrants arriving at the Greek shores significantly decreased to a total of 173,450 arrivals, of which $37 \%$ were children. An estimated $8 \%$ of the total number of these children $(5,192)$ were not accompanied by an adult parent/legal guardian or had been separated from their parents. ${ }^{7}$ These children and young people are officially known as Unaccompanied Children (UAC) or Unaccompanied Minors (UAMs), or more recently as Unaccompanied and Separated Children (UASC) (Demeli 2011). According to recent estimates, the number of UAMs currently residing in Greece is 2,500, the vast majority of them being males over the age of $14 .^{8}$

The Transit Shelter for UAMs [Xenonas Filoxenias Asinodefton Anilikon] was one of nine residence sites on the island of Lesvos providing shelter for unaccompanied refugee children and young people between May 2016 and July 2017, ${ }^{9}$ until a major reallocation of funds for the management of the crisis resulted in its closure. O xenonas (the guesthouse, in the official discourse) or to spiti (the home, as it was often called by the NGO employees at the shelter) was a renovated neo-classical detached house with a spacious garden located close to the port of Mytilene, the island's capital. The shelter, which had the capacity to accommodate up to 22 minors, was run by a Greek NGO, to which we give the pseudonym Horizon, and was funded by an international NGO. Although o xenonas was supposed to function only as a site of transitional accommodation, owing to a lack of more permanent residence facilities in mainland Greece it had actually become a semi-permanent shelter for unaccompanied minors.

At the time of fieldwork, o xenonas housed 20 to 22 unaccompanied or separated boys and young men aged between 12 and 18 and originating from Syria, Afghanistan, Iran, Pakistan, Morocco, Somalia, and Ghana. The allocation of their accommodation had been based on a decision of the UAM's legal guardians. The shelter's residents, with an average stay of 10 
months, were either asylum seekers in Greece, candidates for family reunification in Greece or in other European countries, or candidates for relocation. Residents who were older than 15 years of age were allowed to leave the shelter alone from 9:00 a.m. until 10:00 p.m., while younger residents could only go out if accompanied by a caretaker. The shelter's employees, most of them Greek, comprised the shelter's coordinator, an education officer who was a teacher, a finance and logistics officer (all three of these were men), as well as one female lawyer, one male social worker, two female psychologists, 12 caretakers (seven women and five men), and five Arabic, Farsi, and Urdu male interpreters. All of them were supervised by the NGO's local coordinator, who was a woman. The male caretakers were aged between 22 and 38 and most of the female caretakers were between 30 and 40 years old. The majority of them had an educational background in social sciences. O xenonas provided 24 -hour care for its guests through three different shifts.

\section{Refugee Education in a Prolonged Transit Situation}

Intercultural education has been a dominant issue on the educational agenda of the Greek state during the last decades (Triandafyllidou and Gropas 2007) but it is only recently that refugee education has reached the top of national educational priorities. As Evthymios Papataxiarchis (2016b: 6) highlights, since the beginning of the refugee crisis in the second half of 2015 and due to the state of emergency, the Greek government has outsourced important domains of the management of the refugee crisis to international agents and NGOs, and has designated the United Nations High Commissioner for Refugees (UNHCR) as coordinating agent. Indeed, in austerity-stricken Greece, the state finds itself in the awkward position of outsourcing particular aspects of the education of refugees-predominately the offering and implementation of non-formal educational services, such as remedial education and recreational activities-to international organizations and NGOs. In this fluid context, which has tested the limits of a country already in deep socio-economic and political crisis (Papataxiarchis 2016c), the Greek Ministry of Education responded relatively quickly. In collaboration with other ministries and agents (including the Deputy Ombudsman for Children's Rights, international organizations such as UNHCR, UNICEF, International Organization for Migration (IOM), local authorities, and NGOs), the Ministry of Education sought to set the regulatory framework for the initial phase of refugee children's access and gradual integration into Greek schools, through the operation of reception classes established for primary and secondary education and operating mainly during the evening.

Nevertheless, throughout the first year of adjustments geared towards the education of refugee children in Greece, rates of regular school attendance have remained relatively low, while provisions for the formal education of youths and refugees older than 15 have been and still are insufficient. ${ }^{10}$ At the same time, the regulatory framework for non-formal educational provisions-offered predominately by agents such as NGOs, camp authorities, and volunteers-has been rather incomplete, although significant efforts towards a more comprehensive regulatory framework have been made both by the state and the Education Sector Working Group (ESWG) led by UNHCR, UNICEF, and Save the Children. In such a context, the non-formal education services for refugees implemented by NGOs and other agents, as well as by individuals and volunteers, have not yet been either systematized or regularized to accord with existing common standards. The content and form of the alternative education services offered is therefore diverse, with some agents developing their own curricula. 


\section{Education in the Shelter}

As our fieldwork revealed, education played a crucial role in the operation of the house. Following the NGO's central administration guidelines, its employees placed great emphasis on the education of the young guests, along with the provision of food, clothing, access to medical care, and legal and psychosocial support. The administration's and employees' emphasis on education seemed to be inextricably associated with the type of funding that the administering organization had obtained for the operation of the shelter. Indeed, the funding agreement was premised on the prerequisite that the hosting agent should demonstrate high rates of regular attendance by its residents in educational activities of various kinds, namely formal, remedial, and recreational. The existence of an on-site education officer, who was a teacher himself, verified this emphasis. Not only was the education officer responsible for organizing and even offering courses to the guests inside the shelter, but he was also responsible for supervising and closely monitoring any other educational or leisure activity in which the guests participated.

Simultaneously, education was a crucial element in shaping the terms of the filoxenia between hosts and guests, that is, between employees/caretakers and youths. Although the participation of the guests in educational activities was allegedly optional, not only did the shelter's employees encourage the youths' active engagement in them throughout the course of their stay at the shelter, but they also anticipated their commitment to such an engagement from the first moment they entered the house. This is evident in the claim made by the shelter's caretakers about the "integration process," when they noted that all newcomers would have to go through this as soon as they were assigned accommodation in the shelter by the legal authorities.

During this process, every new guest was informed by a social worker about the residence's rules, regulations, and provisions. An integral part of this informal contract was, on the one hand, the employees' duty to ensure and guard a guest's education, and on the other hand, a guest's commitment to take part in a range of educational activities throughout the time of their stay. In this sense, as other ethnographic studies on hospitality and refugees in Greece have also demonstrated, filoxenia is conditional (Rozakou 2012: 568), often framed by a type of informal contract proposed or indirectly implied by the host agent which entails "rules' and the control, supervision, and education of the guest" (ibid.). These rules and regulations gain additional significance in the particular context of scarcity of safe and appropriate accommodation for UAM.

At the level of everyday life, field research verified the youngsters' engagement in mainly remedial and recreational educational activities, since school attendance was limited due to bureaucratic obstacles. In fact, in October 2016, only four integration classes operated on the island, with a maximum capacity of 11 children each, for pupils up to 12 years of age. During fieldwork, most of the young residents did regularly take part in educational activities under the supervision of the appointed caretakers, who constantly monitored their progress. Specifically, out of the 22 residents of the shelter, only a 12-year-old boy from Syria was registered in regular school and four others aged between 16 and 17 years old attended evening school classes. The rest attended one or more remedial or recreational activities on a regular basis, such as language courses (mainly Greek, English, and Arabic), math and physics classes, IT courses, drama, music, and painting courses, hip-hop or break-dance classes, yoga, jogging, and football training, which took place either on site or off site at special facilities such as education centers, laboratories, stadiums, dance schools, and conservatories. The caretakers regularly contacted the youngsters' teachers and coaches to obtain information about their performance, assisted them during studying hours and with their homework, and communicated their progress to the education officer. 
Taking part in educational activities was assessed positively overall by most youths, even though it was clear that the majority of them were preoccupied with other issues: issues relating to their legal status (i.e. the process of their application for asylum, relocation, or reunification), their transfer to a new accommodation site, delays in the fulfillment of their parents' and relatives' expectations for work due to a prolonged period staying in Lesvos, and mixed feelings, including the guilt of having escaped a war zone.

For those attending school classes, and particularly those who were seeking asylum in Greece, participation in formal education has become synonymous with (re)gaining a kind of visibility and legitimization of their presence within wider society. The words of 16-year-old Riaz from Pakistan, who claimed that since he had started school he had become positively visible in Greek society and even legitimate to Greek authorities, are indicative of this stance:

Before, at the beginning, I didn't take part in classes, we are all day here, watch movie, food, sleep and then one day I went to class. Before going to class I was not good, now I am good, because here in this house we have the chance to make our future. We can do school . . . activities it is better for us, for example, some boys they don't know how to speak, they don't speak a lot, they can paint, and this is very good thing to do, so it's very good to do activities. $\cdots$

The main thing is that people are afraid of us, the people here, the Greek people they don't know what we are. Before they looked us like they want to kill us when we walk, and before I didn't want to go outside, if someone look like that I don't feel good, and after I say what can I do, I'll try to start my lessons and now is little good, now we know little language, like we can speak if someone says to us something. It helps now we speak the language and have friends. . .

$\ldots$

In my life in Pakistan I didn't go to a police station, and in my family anybody don't go. Here one time I went, because we coming back from school, with four children and they said to us give your papers and we go to the police station, when they put us to the car they said to us, you have knife, and we said in the bags we have books, how can we have knife and they say open your bags and they see we had books, and they didn't put the thing like that to our hands (handcuffs), they are students, and we put inside the car relax, and that was good, I like it little. . .

It also became evident through fieldwork that almost all youths enjoyed taking part in certain remedial and recreational educational activities. For most of them, participation in a wide range of off-site activities, such as language courses, football and basketball, music, painting, and break-dance classes, was a source of excitement. The youngsters' engagement in educational and recreational activities was not limited to the courses provided by the shelter's administration and staff, but extended to other activities (such as running) frequently organized by the youths themselves. The significance the youths attributed to these activities was primarily mirrored in the amount of time they spent in taking good care of their appearance when preparing themselves for an activity.

Clearly, off-site educational activities were more successful in terms of rates of participation than the on-site educational activities initially scheduled by the shelter's employees. For most of the boys and young men, their involvement in off-site non-formal educational activities constituted not only a source of significant socialization with other refugees and non-refugees (including female youths), but also an important activity that took their mind away from the constant anxiety about their future. According to 16-year-old Ebo from Ghana: "It is very good, because when you go to a class or program you preoccupy yourself with that, so you stop think- 
ing about whether I'm leaving or not or what's happening, so it is good for you to be preoccupied with other things, you don't think about your situation."

By contrast, in-house non-formal educational activities organized by the shelter's administration and its employees-such as courses in math and physics, IT, and the Greek and English languages, as well as drama classes-did not attract much interest and often had to be canceled. Most of the time, when on-site courses were scheduled, the youths did not show up, making up various excuses, such as pretending to sleep or to be ill. As the education officer in the shelter admitted, on-site classes were not operating as planned because the young residents saw the shelter as home rather than an educational site: "The boys cannot concentrate and take classes seriously in the same place where they eat and chat. Some stay in their rooms and pretend they sleep."

However, the more the youths got involved in off-site remedial and recreational activities, the more they used the house as a locus of practice or exercise of what they had learnt outside, often seeking the assistance of their caretakers in the shelter. For instance, one afternoon the ethnographer was sitting together with four youngsters in one of the house's shared rooms, where one of them was watching break-dance videos on YouTube and trying to copy some steps. A second one was playing the guitar with a caretaker, a third was writing music, and the fourth was drawing on a sketch-block. Although the on-site non-formal educational sessions organized by the administration and the caretakers operated poorly or were even called off, unplanned and unstructured study sessions started taking place, gradually taking the form of one-to-one lessons for the young residents. These private educational sessions were prompted by young individuals who asked for their caretakers' support with their assigned homework for school, or for off-site courses. For example, for 17-year-old Farouz from Iran, the sessions served the following:

... there is not really the need for classes in the house, basically it's the subjects we study in school and we have difficulties with them, we ask the workers, in the house what to do with it, and they explain to us this is how to do it and this is how to understand it...

Interestingly, although the private support classes were gradually incorporated into the daily life of the shelter, they maintained their spontaneous and flexible features. Indeed, they were neither temporally nor spatially defined and could take place at any time of the day or evening upon request and anywhere in the house, including the dining table, the living room sofa, or on the veranda, often in parallel with other activities, such as chatting, playing games, eating, and so on. Furthermore, the youths requested that specific members of staff undertake these informal sessions. The preferred person could be a caretaker, a psychologist, or even an interpreter, and only rarely the social worker, the education officer, or the shelter's chief officer. In most cases, it would be a member of staff with whom they had spent a lot of time and had developed a close relationship, based on a certain degree of intimacy and trust. Often, small groups of two or three youngsters studied together, with one of them occasionally assuming the role of the teacher.

Thus, the youths pursued a type of unstructured in-house support session geared towards their individualized needs, priorities, and desires, which extended beyond mere educational support. Indeed, not only did they seek educational support on their own terms, but they also sought to attract the attention of favorite members of staff. The young residents, through seeking the engagement of their caretakers in learning processes, on the one hand reversed aspects of the terms of the informal contract of filoxenia - the rules and regulations relating to their active engagement in educational activities-while on the other hand they renegotiated contractual asymmetries in their relationships with their caretakers. Intriguingly, this happened through the re-appropriation by the youths of both dominant conceptualizations of domesticity as incom- 
patible with structured (formal-like) educational processes, and of mainstream perceptions of children and youth in need of education. Acknowledging the importance of the subjectivity of the student within the regulatory framework of a shelter for unaccompanied youth and children, the youths instrumentally positioned themselves as students in order to secure the desired care from their caretakers, simultaneously making themselves visible in the house by fulfilling their educational obligations.

\section{The Contractual Dimension of Education in the Context of Filoxenia: Cracks and Ruptures}

To a certain extent, the shelter's young residents challenged aspects of the informal contract of filoxenia by reversing the form and content of the formal-like courses offered in the house to meet their own requirements. Yet they kept reproducing this "contract" through enriched ways of engaging with learning processes. At the same time, the more the youths responded to this plural engagement, the more the shelter's employees tended to orient them towards the mainstream curricula, which resulted in tight weekly schedules in terms of timetables, homework, and extra-curricular activities.

The reaction of the shelter's youngest resident, 12-year-old Ahmed, towards his teacher and education officer after a day of exhausting activities reflects exactly this: ". . . me come home, Greek, eating, English and sleeping. Training three times per week and me eat, read, sleep and train." A similar reaction also came from 16-year-old Naeem from Pakistan when he returned to the shelter from football training: "Oh, come on Horizon [the NGO that runs the shelter], football, Greek, English, tired, Nadina [the ethnographer]" [meaning that he got tired undertaking all these activities]. In addition to the young residents' tight weekly schedules of educational activities, their attendance and performance were also scrutinized by the shelter's staff through a sophisticated method that tended to resemble mainstream educational evaluation. Indeed, the supervision, monitoring, and assessment of youths' educational performance gradually became a daily routine in the shelter. The education officer was recording and assessing the residents' rates of attendance, performance, and overall eagerness to participate in educational activities through a sophisticated online system with charts and graphs.

Undoubtedly, the unofficial discourse on filoxenia in the context of the shelter for unaccompanied youths, as reproduced by the caretakers, is closely linked with the dominant discourse on the vulnerability of underage people on the move. Representations of children and young people on the move, who lack both moral and physical surveillance by parents, contrast with conventional conceptualizations of childhood and youth cast in need of protection, restricted to home and other designated spaces (such as schools, playgrounds, etc.), and under the moral and physical surveillance of parents and family members (James et al. 1998; Stephens 1995). In this sense, the practices of filoxenia deployed by the caretakers through embracing formal-like educational curricula invoked the production of docile bodies through disciplinary techniques and surveillance (Foucault 1977). While most of the young guests felt the pressure of a tight schedule, they nevertheless carried on with their engagement in educational activities in order to fulfill what was seen by their caretakers and wider society as appropriate for their age and expected in the framework of filoxenia. In other words, most of the residents in the shelter appropriated the dominant expectation of the young xenos: to be a good student both metaphorically (as an imagined student who seeks to attain a certain degree of Greekness) (Papataxiarchis 2006: 7) and literally (as a student who performs well in learning processes) in the framework of the contract of filoxenia. 
Yet, when rifts and misunderstandings over small or big issues between caregivers and guests created an atmosphere of tension in the shelter, the youths often sought to challenge their caretakers' authority over their educational engagements by causing fractures in the established arrangements concerning their engagement in learning provisions. Characteristic of this is the example of the attitude of 12-year-old Ahmed from Syria who, following a misunderstanding with the shelter's coordinator, immediately ran to his bedroom and started ripping up his school books and notebooks and throwing the small pieces of paper along with his pencil case out of his window. Youths' reactions of this kind, which reflect their awareness of the symbolic weight of openly challenging reciprocal relatedness in the house through contesting learning processes, indicate possible cracks in the contract of filoxenia. The final rupture, though, comes inevitably with the formal announcement of a youth's transfer to another accommodation site.

Throughout our visits to the shelter, the staff occasionally announced decisions made by the attorney or the asylum service-based on various causes, such as difficulties in adapting, adulthood, authorization of legal request, and so on-on the transfer of certain youngsters to another accommodation site in Athens. As soon as the youngsters were informed that they would be transferred, they instantly withdrew from all the educational activities in which they had been participating thus far. For instance, when 16-year-old Sajad from Pakistan found out that his transfer to a shelter in Athens was imminent, he immediately decided to stop attending off-site Greek and English courses at a language center in Mytilene. However, Sajad, along with his housemate and classmate Naeem, who was also informed of his forthcoming transfer, asked the shelter's staff to be allowed to pay one more visit to the center in order to say goodbye to the teachers.

This happened despite the youngsters having been informed that the period between the announcement of the decision and the actual transfer could be quite long (ranging from one week to two months without anyone ever knowing the exact waiting period). Irrespective of this, they immediately gave up all on-site and off-site educational activities. In some cases, youngsters retreated from any kind of social life outside the residence and passed most of their time inside the house, while in other cases youngsters even isolated themselves from their co-inhabitants, watching television for hours or spending most of their time in their rooms, causing ruptures and discontinuities in the everyday life of the house. These results verify other studies on youth which demonstrated that when legal/institutional processes disrupt young people's routines related to their future plans, they often disengage from education (Sigona et al. 2017).

Surprising, though, was the fact that following the announcement of the decision for a resident's transfer, and based on his decision to give up educational engagements, the caretaker's preoccupation with the youngster's educational provision was also considerably reduced. In this transitional period before transfers, although the caretakers were clearly available to engage with them in various aspects of domestic sociality, they acknowledged the youths' need to distance themselves from educational provisions in order to facilitate their transition from a context of relative stability in the house to a new, unknown condition.

From the results described above, it seems that the youths' engagement in educational activities offers a sense of permanency and normality that is tied to the domestic realm of the house and the interdependencies of relationships produced there. Once news about relocation upsets this sense, then participation in educational processes becomes redundant. Although such events were clearly experienced by residents and carers alike as causing major disruptions in the daily routines of the house, they were also recognized by the carers as a necessity, primarily for those who were to be transferred from the shelter and who thus had to come to terms with new 
discontinuities in their lives. In the event of an imminent relocation, when all parties realized that the time of filoxenia had elapsed, the reduced emphasis on educational provisions by the carers was replaced by their enhanced preoccupation with the emotional state of the youths to be transferred. At this point, the carers primarily sought to relieve the youths' anxieties about an unknown future and reduce the distress caused by the upcoming detachment from the sense of permanence and normality they had attained in the house.

\section{Conclusion}

By focusing on educational processes taking place in the framework of the operation of a Transit Shelter for Unaccompanied Minors in Lesvos, we have sought to explore the young male residents' stance towards engagement in formal, remedial, and recreational activities anticipated by their caretakers and other shelter employees. The carers' and staff's anticipation of youths' active participation in learning and leisure activities is premised on the reciprocities embedded in relational processes in the framework of a specific hospitality order that positions refugee youths both as temporary guests and as subjects in need of discipline in the residency. The asymmetries and power relations produced in the shelter in the framework of filoxenia are inscribed in a wider context which increasingly places education at the core of the dominant discourse on how to manage the refugee crisis in Greece.

Specifically, we have explored the terms of the informal contract of filoxenia in the shelter and the concomitant reciprocal relations developed between caretakers and youths, revolving around the provision of education by the caretakers and engagement with education by the youths. In doing so, we have argued that most of the young filoxenoumeni in the shelter tried to conform both to their carers' and to wider society's expectations of the young xenos to be a "good student" and thus a "good guest." However, although the young guests were careful not to jeopardize the overall framework of filoxenia, they appropriated the expected role of the student in ways that enabled them to act upon the top-down agenda of education initially imposed by the shelter's employees.

Drawing on mainstream views of the student who is confined to designated spaces other than the domestic sphere, the young residents opted for educational activities outside the residential home rather than structured in-house educational activities. Simultaneously, drawing on dominant perceptions of domesticity and domestic order, and culturally significant perceptions of relatedness in the domestic realm, they pursued individualized in-house learning sessions with preferred caretakers and employees. In fact, through invoking the obligation of their caretakers to ensure educational provisions for their guests, the youths sought to engage in more attentive relationships with them, while also consolidating the image of a "good student" and a "good guest." These outcomes indicate a reversal of the terms in which filoxenia is framed in the context of the shelter. Not only do the young guests negotiate their participation in educational and learning activities, but they also negotiate the very terms of the informal contract of filoxenia at the residential site. However, this seems to become non-functional when the offering of filoxenia by caregivers and the fulfillment of educational obligations by young residents are no longer an issue.

The youngsters' abrupt withdrawal from educational activities and their caregivers' concomitant withdrawal from educational provisions indicate the reciprocal dimension of the relationship between hosts and guests when it is premised on the expectation of obligation on the part of the young residents to engage themselves in education. At the same time, the very same process of disengagement from learning processes, by both the youths and their caretakers, signifies 
the inevitable gradual detachment of youths and carers alike from the interdependencies of relatedness that is inscribed in the terms of filoxenia within a particular context of domesticity in the shelter.

The findings of this case verify comparative ethnographic material produced through fieldwork undertaken in the framework of the PRESS Project in Greece (see note 3), on various refugee groups' differentiated attitudes towards educational programs, ranging from non-participation or irregular attendance to full participation, within and across different accommodation sites in the country. An important finding is relevant here: that these differentiated attitudes are closely linked to spatially defined social relationships developed between the refugees/guests or recipients of filoxenia and significant others/hosts who offer filoxenia (e.g. those engaged in the humanitarian sector and/or non-refugee others) within the specific structures in which refugees are being accommodated, and in the surrounding localities.

Nonetheless, the terms through which filoxenia is being practiced, involving arrangements and expectations related to education in the context of the biopolitics of humanitarianism, extend beyond the spatial frameworks of hosting structures and specific localities to wider society, state policies, and practices. Paradoxically, both in official and unofficial discourse, educational provisions are seen as an empowering, non-tangible gift provided by hosting agents towards the refugees, while, simultaneously, the refugees' participation in educational processes constitutes a means of reciprocation anticipated by the hosts. These expectations for the refugees to engage in education, reproduced in the discourse on humanitarian agents, are often linked with provisions of accommodation, particularly in the case of the most vulnerable members of the refugee population, the UAM.

IVI DASKALAKI studied Social Anthropology at Goldsmiths University of London, where she also completed her $\mathrm{PhD}$ thesis on a post-nomadic group of Gypsies in Greece. She has taught courses on Social Anthropology at Panteion University, the University of Crete, and the University of Ioannina. She has carried out research and published on Gypsies, childhood and education in Greece, street-working children and youths in Athens, immigrant paid domestic workers in Athens, and assisted reproduction, kinship, and religion in Greece. Recently, she has coordinated a research program on refugee education in Greece. She has co-authored the book Out of Body, Out of Home: Assisted Reproduction, Gender and Family in Greece (Alexandria, 2015).

NADINA LEIVADITI studied Social Anthropology and History at the University of the Aegean and earned her MA in "Research in Architecture: Architectural Design, Space, Culture" at the National Technical University of Athens. Her MA thesis is based on unaccompanied refugee minors in Lesvos. She has significant experience in the humanitarian sector as a practitioner working with refugee children and youth in Athens and Lesvos, where she was Local Coordinator of a range of programs for "Children on the Move." She is currently working as a field researcher on refugee education in Lesvos in the framework of Project PRESS funded by the Hellenic Open University. 


\section{NOTES}

1. http://www.consilium.europa.eu/en/press/press-releases/2016/03/18-eu-turkey-statement/ (last accessed 19 October 2018).

2. Retrieved 19 October 2018 https://data2.unhcr.org/en/documents/download/60119 (last accessed 19 October 2018).

3. For more information, see http://www.press-eap.net/ and http://press-project.eap.gr/toolkit/ (last accessed 19 October 2018).

4. The ethnographic material discussed here is based on fieldwork by Leivaditi.

5. With reference to this article, the youths who took part in the research mainly preferred to express themselves in both Greek and English, rather than using an interpreter.

6. https://data2.unhcr.org/ar/documents/download/53447 (last accessed 19 October 2018).

7. https://reliefweb.int/sites/reliefweb.int/files/resources/55971.pdf (last accessed 19 October 2018).

8. https://data2.unhcr.org/en/documents/download/59187 (last accessed 19 October 2018).

9. https://data2.unhcr.org/en/documents/download/58570 (last accessed 19 October 2018).

10. https://www.unicef.org/eca/sites/unicef.org.eca/files/eca-dataprod-FINAL_ENGLISH_VERSION .pdf (last accessed 19 October 2018).

\section{REFERENCES}

Amit-Talai, Vered, and Helena Wulff, eds. 1995. Youth Cultures: A Cross-Cultural Perspective. London: Routledge.

Anderson-Levitt, Kathryn M. 2011. "World Anthropologies of Education." In A Companion to the Anthropology of Education, ed. Mica Pollock and Bradley A.U. Levinson, 11-24. New York: Wiley-Blackwell.

Anderson-Levitt, Kathryn M. 2012. "Introduction: Anthropologies and Ethnographies of Education Worldwide." In Anthropologies of Education, ed. Kathryn M. Anderson-Levitt, 1-28. New York: Berghahn Books.

Athanasiou, Athena. 2017. "States of Emergency, Modes of Emergence: Critical Enactments of 'The People' in Times of Crisis." In Critical Times in Greece: Anthropological Engagements with the Crisis, ed. D. Dalakoglou and G. Agelopoulos, 15-31. London: Routledge.

Best, Amy, ed. 2007. Representing Youth: Methodological Issues in Critical Youth Studies. New York: New York University Press.

Boyden, Jo, and Joanne de Berry, eds. 2004. Children and Youth on the Front-Line: Ethnography, Armed Conflict and Displacement. Oxford: Berghahn Books.

Cabot, Heath. 2013. "Engagements and Interruptions: Mapping Emotion at an Athenian Asylum Advocacy NGO." In Ethnographies of Social Support, ed. Friederike Fleischer and Markus Schlecker, 141-159. London: Palgrave.

Cabot, Heath. 2014. On the Doorstep of Europe: Asylum and Citizenship in Greece. Philadelphia: University of Pennsylvania Press

Carsten, Janet. 2004. After Kinship. Cambridge: Cambridge University Press.

Chatty, Dawn. 2007. "Researching Refugee Youth in the Middle East: Reflections on the Importance of Comparative Research." Journal of Refugee Studies 20 (2): 265-280. https://doi.org/10.1093/jrs/ fem005.

Chatty, Dawn, ed. 2010. Deterritorialized Youth: Sahrawi and Afghan Refugees at the Margins of the Middle East. New York: Berghahn Books.

Chatty, Dawn, Hashem Ahmadzadeh, Metin Çorabatir, Jalal Al Husseini, Leen Hashem, and Sarah Wahby, eds. 2014. Ensuring Quality Education for Young Refugees from Syria (12-25 Years): A Mapping Exercise. Research Report, Refugee Studies Centre, Oxford Department of International Development, University of Oxford. 
Christensen, Pia, and Allan Prout. 2002. "Working with Ethical Symmetry in Social Research with Children." Childhood: A Global Journal of Child Research, 9 (4): 477-497.

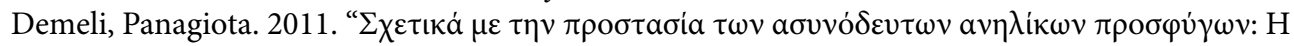

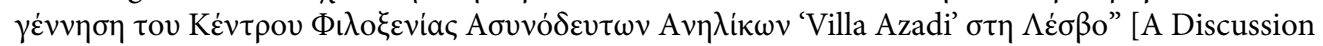
of the Protection of Unaccompanied Underaged Refugees: The Founding of the Accommodation

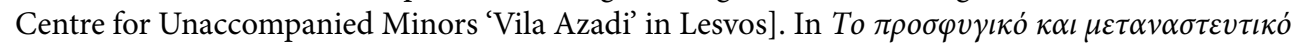
$\zeta \dot{\eta} \tau \eta \mu \alpha$ [The Refugee and Migration Problem] (in Greek), ed. Sevasti Troumbeta, 243-275. Athens: Papazisi.

Dryden-Peterson, Sarah. 2015. The Educational Experiences of Refugee Children in Countries of First Asylum. Washington, DC: Migration Policy Institute.

Dryden-Peterson, Sarah. 2017. "Refugee Education: Education for an Unknowable Future." Curriculum Inquiry 47 (1): 14-24.

Du Boulay, Jill. 1991. "Strangers and Gifts: Hostility and Hospitality in Rural Greece." Journal of Mediterranean Studies 1: 37-53.

Fiddian-Qasmiyeh, Elena. 2015. South-South Educational Migration, Humanitarianism and Development: Views from the Caribbean, North Africa and the Middle East. Oxford: Routledge.

Fiddian-Qasmiyeh, Elena, Gil Loescher, Katy Long, and Nando Sigona, eds. 2014. The Oxford Handbook of Refugee and Forced Migration Studies. Oxford: Oxford University Press.

Foucault, Michael. 1977. Discipline and Punish. London: Allen Lane.

Hart, Jason, ed. 2008. Years of Conflict: Adolescence, Political Violence and Displacement. Oxford: Berghahn Books.

Hart, Jason. 2014. "Children and Forced Migration." In The Oxford Handbook of Refugee and Forced Migration Studies, ed. Elena Fiddian-Qasmiyeh, Gil Loescher, Katy Long, and Nando Sigona, 383394. Oxford: Oxford University Press.

Herzfeld, Michael. 1987. “'As in Your Own House': Hospitality, Ethnography, and the Stereotype of Mediterranean Society." In Honor and Shame and the Unity of the Mediterranean, ed. David D. Gilmore, 75-89. Washington, DC: American Anthropological Association.

Herzfeld, Michael. 1997. Cultural Intimacy: Social Poetics in the Nation-State. New York: Routledge.

Holmes, Prue, Richard Fay, Jane Andrews, and Mariam Attia. 2013. "Researching Multilingually: New Theoretical and Methodological Directions." International Journal of Applied Linguistics 23 (3): 285-299.

Hos, Rabia. 2016. "Education in Emergencies: Case of a Community School for Syrian Refugees." European Journal of Educational Research 5 (2): 53-60. http://files.eric.ed.gov/fulltext/EJ1099651.pdf.

James, Alison, Chris Jenks, and Allan Prout. 1998. Theorising Childhood. Cambridge: Polity Press.

Korbin, Jill E. 2003. "Children, Childhoods, and Violence." Annual Review of Anthropology 32: 431-446.

Levine, Robert A. 2007. "Ethnographic Studies of Childhood: A Historical Overview." American Anthropologist 109 (2): 247-260.

Levinson, Bradley A. U., and Micka Pollock. 2011. “Introduction”. In A Companion to the Anthropology of Education, ed. Bradley A. U. Levinson and Micka Pollock, 1-8. New York: Wiley-Blackwell.

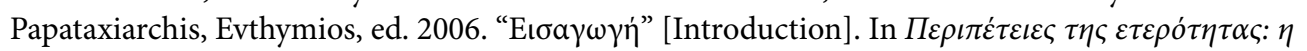

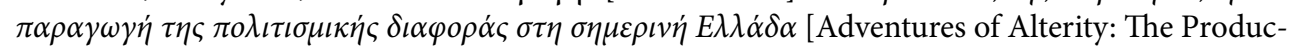
tion of Cultural Difference in Contemporary Greece] (in Greek), ed. Evthymios Papataxiarchis, 1-85. Athens: Alexandria.

Papataxiarchis, Evthymios. 2016a. "Being 'There': At the Front Line of the 'European Refugee Crisis' (Part 1)." Anthropology Today 32 (2): 5-9.

Papataxiarchis, Evthymios. 2016b. "Being 'There': At the Front Line of the 'European Refugee Crisis' (Part 2)." Anthropology Today 32 (3): 3-7.

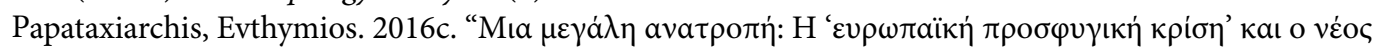

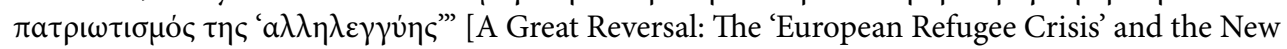
Patriotism of 'Solidarity'] (in Greek). Sichrona Themata 132-133: 7-28.

Papataxiarchis, Evthymios. 2016d. "Unwrapping Solidarity? Society Reborn in Austerity." Social Anthropology 24 (2): 205-210. 


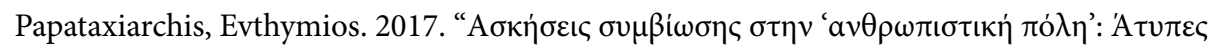

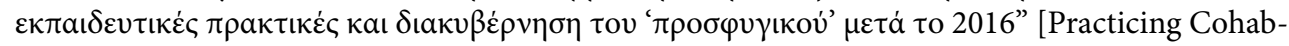
itation in the 'Humanitarian Town': Informal Educational Practices and the mManagement of the 'Refugee Crisis' since 2016] (in Greek). Sichrona Themata 137: 74-89.

Papataxiarchis, Evthymios, Pinelopi Topali, and Aggeliki Athanasopoulou. 2009. Kó

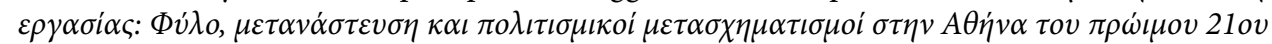
$\alpha \iota \omega v \alpha$ [Worlds of Domestic Work: Gender, Migration and Cultural Transformation in Athens in the Early 21st Century] (in Greek). Athens: Alexandria.

Punch, Samantha, and Kay Tisdall, eds. 2013. Children and Young People's Relationships: Learning across Majority and Minority Worlds. New York: Routledge.

Rakopoulos, Theodoros. 2015. "Solidarity's Tensions: Informality and Sociality in the Greek Crisis." Social Analysis 59 (3): 85-104.

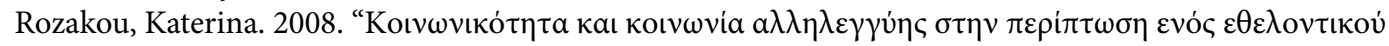
$\sigma \omega \mu a \tau i o v "$ [Sociality and Solidarity Society in the Case of a Voluntary Association] (in Greek). Elliniki Epitheorisi Politikis Epistimis 32: 95-120.

Rozakou, Katerina. 2012. "The Biopolitics of Hospitality in Greece: Humanitarianism and the Management of Refugees." American Ethnologist 39 (3): 562-577.

Rozakou, Katerina. 2016. "Socialities of Solidarity: Revisiting the Gift Taboo in Times of Crises." Social Anthropology 24 (2): 185-199.

Sahlins, Marshall. 2013. What Kinship Is and Is Not. Chicago: University of Chicago Press.

Scientific Committee for the Support of Refugee Children (Ministry of Education, Research and Reli-

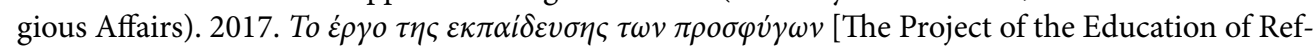
ugees]. Athens: Ministry of Education, Research and Religious Affairs.

Sigona, Nando, Elaine Chase, and Rachel Humphris. 2017. "Understanding Causes and Consequences of Going 'Missing"' Becoming Adult Brief no. 6, UCL, London. http://www.becomingadult.net.

Stephens, Sharon, ed. 1995. Children and the Politics of Culture: Rights, Risks and Reconstructions. Princeton, NJ: Princeton University Press.

Triandafyllidou, Anna, and Ruby Gropas. 2007. "Greek Education Policy and the Challenge of Migration: An Intercultural View of Assimilation." ELIAMEP. http://www.eliamep.gr/wp-content/ uploads/en/2008/10/greek_education_policy_and_the_challenge_of_migration_triandaf_and_ gropas_emilie_wp3_22_nov_07.pdf. 